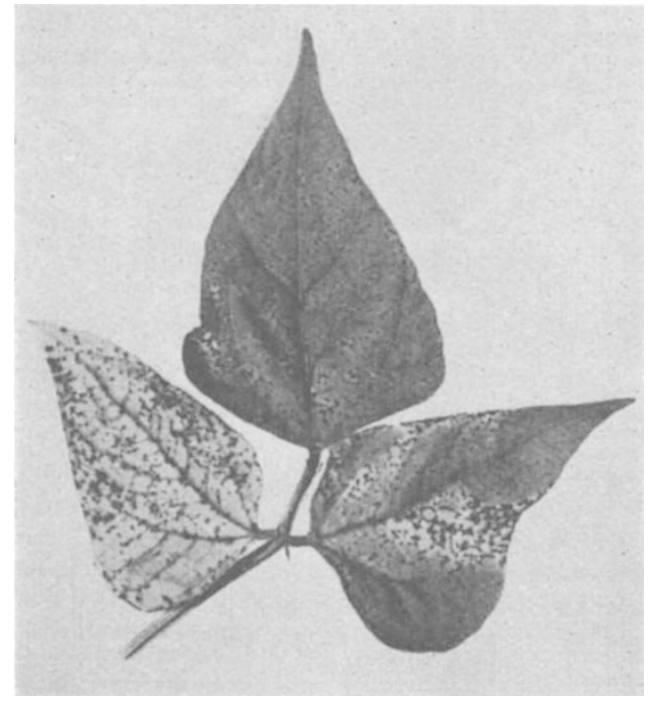

Fig. 1. The typical effects produced on bean leaves by the various species of $\boldsymbol{X}$ anthomonas

proof that the bacteria had become adapted to their new host. This type of infection could not invariably be distinguished from that caused by $X$. phaseoli, though this organism frequently caused a more extensive pale green necrosis and wilting. It seems possible that the organisms originally isolated from other hosts would, with further adaptation to the bean, produce symptoms identical with those due to $X$. phaseoli. Single-colony isolates were in each case shown to be indistinguishable in cultural and physiological properties from their parent culture. The ability of $X$. phaseoli var. fuscans, $X$. punicae and $X$. ricinicola to produce a brown stain in media was a convenient label for these organisms, and provided evidence that unintentional cross-infections did not occur.

There seems to be no reason to suppose that the inoculations were carried out under unnatural conditions. Actively growing bacteria were merely applied in sufficient numbers to susceptible parts of bean plants under the conditions of humidity and temperature which commonly promote infection in temperate and sub-tropical elimates. The findings suggest the possibility that a similar result might be obtained with other hosts and that the host specificity of the xanthomonads may not be a stable character. The fact that cultures originally isolated from twenty different hosts can infect bean plants is, at the least, evidence of a close relationship among these organisms.

I am grateful to the New Zealand Fruitgrowers Federation, Ltd., and to the Department of Scientific and Industrial Research, New Zealand, for financial assistance which made this work possible.

Bacteriology Department, D. W. DYE*

College of Agriculture,

Edinburgh. Oct. 20.

* Present address : Plant Diseases Division, Private Bag, Auckland, New Zealand.

${ }^{1}$ Burkholder, W. H., and Starr, M. P., Phytopath., 38, 494 (1948).

'Stapp, C., "Handbuch der Pflanzen-krankheiten", Band 2 (Paul Parey, Berlin and Hamburg, 1956).

${ }^{3}$ Bergey's "Manual of Determinative Bacteriology", 7th edit., edit. by Breed, R. S., Murray, E. G. D., and Smith, N. R. (Baillière,

- Wernham, C. C., Phytopath., 38, 283 (1948).

\section{Preparation of Virus Antisera from Strawberry}

STRAWBERRY contains tanning agents in such quantity that water extracts of strawberry leaves contain no appreciable amounts of protein and will, moreover, precipitate serum proteins, thus being unsuitable for serological work with viruses that infect the plant ${ }^{1}$. This is also true of other rosaceous plants, and thus most workers have tried to find other hosts for viruses affecting members of the Rosaceae before attempting the preparation of specific antisera.

It now seems that this step is not necessary in preparing antisera to some viruses from rosaceous plants, since by the use of recent techniques for the removal of tanning agents from leaves during maceration ${ }^{2}$, satisfactory antisera have been prepared to two viruses from strawberry leaves, namely, raspberry ringspot virus from the variety Huxley, and raspberry yellow dwarf virus from the variety Cambridge Favourite. Both these are soil-borne viruses which are widespread and of local importance in strawberry in Scotland, and they can be transmitted mechanically from strawberry to a number of herbaceous host plants ${ }^{3}$.

In each case, leaf extracts were prepared by the following method, found to give a high yield of virus in preliminary investigations in which extracts prepared in various ways from Huxley strawberry infected with raspberry ringspot virus were assayed on the leaves of Chenopodium amaranticolor (Coste and Reyn.) plants.

Mature leaves harvested from infected plants in the field were shredded and then ground in a mortar with an equal weight of 5 per cent nicotine base and sufficient coarse carborundum powder to ensure thorough maceration. The liquid expressed by squeezing the macerate through muslin was then clarified by slow-speed centrifugation and dialysed against running tap-water overnight to remove excess nicotine. After further dialysis against 0.85 per cent saline, the preparations were stored frozen. Antisera were prepared by the intravenous injection to rabbits of $2 \mathrm{ml}$. aliquots of these preparations at twiceweekly intervals over a period of three weeks. Both antisera were of moderately high titre-about 1/256 - measured by precipitin tests against clarified sap from infected leaves of Petunia hybrida Vilm. This titre compares well with those obtained using infected $P$. hybrida or Nicotiana tabacum L. as the source of virus. It is of interest that the viruses in preparations made in this way did not give a visible precipitate when incubated with their homologous antisera, but did so only if concentrated after precipitation with acetone.

It is thought that this method, refined by the use of ultracentrifugation or freeze-drying, may be of value in preparing antisera to other viruses directly from rosaceous hosts. A fuller account of the development of the method is to be published elsewhere.

\section{R. M. LISTER}

Scottish Horticultural Research Institute, Invergowrie, by Dundee. Oct. 15.

1 Bawden, F. C., and Kleczkowski, A., J. Pomol., 21, 2 (1945).

${ }^{2}$ Cadman, C. H., J. Gen. Microbiol., 20 (in the press).

${ }^{3}$ Lister, R. M., Plant Path., 7, 92 (1958).

- Harrison, B. D., Ann. App. Biol., 46. 462 (1957); 46, 221 (1958). 